International Journal of English Literature and Social Sciences
Vol-6, Issue-4; Jul-Aug, 2021

Peer-Reviewed Journal

\title{
Finding Meaning in the Absurd
}

\section{Mit Sagar}

\author{
Gujarat university, Ahmedabad, Gujarat, India
}

Received: 11 Jul 2021; Received in revised form: 16 Aug 2021; Accepted: 24 Aug 2021; Available online: 01 Sep 2021

(C2021 The Author(s). Published by Infogain Publication. This is an open access article under the CC BY license

(https://creativecommons.org/licenses/by/4.0/).

\begin{abstract}
The purpose of this study is to textually analyze two works, namely The Myth of Sisyphus by Albert Camus and Metamorphosis by Franz Kafka to describe the contradiction and similarities in the Idea of Absurdism in the two respective works.

Absurdism has often been neglected as a philosophy of despair, while the truth is quite the contrary; this was elucidated by one of the major Absurdist writers, Albert Camus who describes Absurdism as the need to battle meaninglessness of life. Camus in his work The Myth of Sisyphus describes how the acceptance of the absurd will open new doors to look at life. Finding purpose in life is an act of meaninglessness that will leave one unhappy and strangled with question but Camus addresses that when you accept the absurdness it will be your rebellion against life. Through the portrayal of Sisyphus, who is punished to roll a huge stone up on the mountain Camus address that we should Imagine him happy even while he is punished because rather than finding meaning he has accepted the absurdness of life which is the reason he is happy.

Often addressed as a pessimistic writer for his view on the world Franz Kafka has a similar point of view and that is depicted in his Novella Metamorphosis. While the protagonist is metamorphosed into a litter vermin, he is revolting against life, even when his own family hates him and his father hit him with a broomstick to get rid of him and his sister alludes that he is not her brother, trapped in his room by his own family from the beginning of the story. Gregor samsa the protagonist is revolting against life to make his own meaning to live. Even with Major aspects, of both the writers falling under the same roof, there are minor contradictions especially when it comes to the death of Gregor Samsa.
\end{abstract}

Keywords-absurd, meaninglessness, camus, kafka, suicide.

\section{INTRODUCTION}

In the early 1900, the world was suffering from lack of intuitiveness. In 1857, with the publication of $O n$ the Origin of Species by Charles Darwin the faith towards god was questioned and was majorly bend towards science. The beginning of the early $20^{\text {th }}$ century was an unusual period and one could sense the powerful silence, the shadows of the world war were lurking from behind, which was taking place because of the bitter relations of different countries fighting to convey power and gain more region in the global map. In a world, which was devoured of hope, people wanted something, a philosophy, an idea that they can hold on to. Something that they can look forward to for a better tomorrow. Friedrich Nietzsche stood firm in his belief and took the philosophy of Nihilism a bit ahead, adding his own belief and ideas to it. Nihilism, wanted people to put their belief and faith in their own self rather than finding it in something else, With phrases like: "God is dead (Nietzsche 197)". The mindset that people were having with their belief questioned in god was used for betterment by Nietzsche to stop them for looking for an external entity for their hope. Thus, we can say that the philosophy of Nihilism was used as a core for the idea of absurdism. Nietzsche was the first of all the modern thinkers to attribute life as meaningless and all the later thinkers in some way took the concept 
from here to make it more meaningful in their own ways. Growing up and living in similar circumstances, the two writers Albert Camus and Franz Kafka saw the world with a lack of hope and they tried to give the world, a better idea of how to overcome it with their works and writings.

Born in a German speaking Jewish family in Prague. Franz Kafka was an outsider from the start because Prague's Jews speak in German, the official language of the Hapsburg Empire. From an early age, Kafka was an alienated kid. With strict parents and never been served with love in its true sense, Kafka was diagnosed with anxiety very early in his life. Kafka's father, Harmann Kafka had a huge impact on Kafka's life. He was an overbearing, authoritarian, who had little taste for literacy and His authoritarian behaviour even made Kafka stopped writing things. In every work of Kafka, we could see his father's impression in some way and above all, in Metamorphosis it is believed that Kafka has portrayed himself as Gregor Samsa, the protagonist of that work. Kafka after his father's peer pressure on his education went on to pursue law and then went on to work as an insurance salesman which is something that even Gregor Samsa did for a living in the story. Kafka struggled his whole life and later was diagnosed with tuberculosis, which ended his life in 1924 (Kafka1-8). With ample of ways to interpret Kafka's work. Kafka has laid the foundation of Kafkaesque in the real world. With different critic bombarding different views on Kafka's work, it is mandatory to highlight both the aspect of his work.

A similar life is been led by the French-Algerian writer, Albert Camus. Growing up in French ruled Algeria, which was fighting for its right, Camus grew up in the middle of destruction and chaos and rather than being a part of it, He went on to turn the wheel for a better future. Camus played an important part in political side of his country but finding his ideas are to no avail, he turned to literature and to philosophy for solace. Camus adores nihilism and he wrote, "I owe part what I am to Nietzsche (Mikics and Robert 203)". Taking the core of nihilism, he went on to portray absurdism as an optimistic ideas for others to follow which was accepted and appreciated wholeheartedly. "Nihilism, which raises the possibility that existence lacks value and purpose, may well be the philosophical question most worth considering. To the extent that nihilism has a human face to American readers, that face belongs to Albert Camus (Mikics and Robert 202)."

Yet, Camus never addresses himself as a philosopher but a novelist and as true as he stands the philosophy that he preaches can be seen in his work.

\section{The Myth of Sisyphus}

The Myth of Sisyphus by Albert Camus is an amalgamation of different essays focused on the ideas of absurdism grabbing different argument on the way to depict how Camus want to portray his idea of absurdism. The book was published in 1942 and it was published in the middle of the second world war, it was an idea, a revolution in some sense, which Camus undertook with this publication, and it gave the great modern thinkers a different lens through which they can see the world. "Camus arranged his writing cycles, each carrying an essay, play, and novel. Fittingly, with each of these cycles he associated a figure from Greek myth. The first cycle, devoted to the theme of the absurd, contained The Stranger ; Caligula, and The Myth of Sisyphus. Not surprisingly, Camus associated this cycle with Sisyphus, the god doomed to heave a boulder up a mountainside, watch it tumble back down, then repeat the effort until the end of time. An absurd task, Camus famously declared - and precisely because it is absurd, fully embraced by Sisyphus (Zaretsky 57)".

\section{Absurdity and Suicide}

The Myth of Sisyphus begins with a profound statement. "There is just one true philosophical problem" Albert Camus writes "and that is of suicide (11)". For Camus, suicide is the most fundamental problem and he begins the book with addressing it, elucidating on the fact that every individual go through a lot in their life but when they come to a conclusion where they can no longer bear life, they go on to kill themselves. Camus while addressing the concept of suicide tries to bring in his own definition of absurdity and its feeling. Camus writes, "A world that can be explained even with bad reasons is a familiar world. But, on the other hand, in a universe suddenly divested of illusions and lights, man feels an alien, a stranger. His exile is without remedy since he is deprived of the memory of a lost home or the hope of a promised land. This divorce between man and his life, the actor and his setting, is properly the feeling of absurdity (The Myth of Sisyphus 13)." Camus gives three major reasons, which lead people to suicide, "The irrational, the human nostalgia, and the absurd... (The Myth of Sisyphus 32)" With the three major reasons stated, Camus goes on to explain how the three major reason play in life and it even lead people to suicide. With the reasons stated here, Camus tries to portray how the same three reason which is been used for suicide can be used for betterment if been seen from a different lens. Camus thus in The Myth of Sisyphus states "...the irrationality of the world and of experience. It thus appears that the bitterly it destroys the reason's preconceptions the more radically he will explain the world. That apostle of humiliated thought will find at the very end of humiliation the means of regenerating being to its very depth (36)." Camus while writing about irrationality want us to accept 
the randomness of universe and accept it. With life being irrational, Camus want us to feel and accept it so we can derive our own meaning regarding it. As sane as it sounds, when people are not been able to see the other side of the tunnel, they go on to kill themselves rather than accepting the irrational, which majorly is out of fear. Camus goes on to write that "The world itself, whose single meaning I do not understand, is but a vast irrational. If one could only say just once: 'this is clear', all would be saved. But these men vie with one another in proclaiming that nothing is clear, all is chaos, that all man has is his lucidity and his definite knowledge of the walls surrounding him (The Myth of Sisyphus 31)". Camus while reflecting the irrationality and acceptance of it, in some way drags an individual away from meaning and to exemplify the irrationality, Camus states in The Myth of Sisyphus

“...people have played on words and pretended to believe that refusing to grant a meaning to life necessarily leads to declaring that it is not worth living. In truth, there is no necessary common

measure between these two judgments (15)." Thus, we can proclaim that with the irrationality being the major reason for suicide and in some way, the one major weapon for absurdism. Camus wants us to live with irrationality and without looking on for meaning.

Albert Camus states that the second major reason for suicide is the human nostalgia, and while explaining this concept, Camus conveys that human curiosity to know things and accept it is limited but in the same manner, the digestion of the meaningless and to keep their faith on it is lacked which lead to major suicides. Camus states, "Our appetite for understanding, our nostalgia for the absolute are explicable only in so far, precisely, as we can understand and explain many things. It is useless to negate the reason absolutely. It has its order in which it is efficacious. It is properly that of human experience (The Myth of Sisyphus 38)."

The final reason that Camus states for suicide is the acceptance of the absurd, which in other words, is meaningless. According to Camus, life is meaningless and the more one tries to find meaning in it, he will be deliberately hurting oneself through it. Thus, the better choice would be to accept the meaninglessness. Camus wrote "...the whole consequence of a life can depend on it. The irrational, the human nostalgia, and the absurd that is born of their encounter - these are the three characters in the drama that must necessarily end with all the logic of which an existence is capable. (The Myth of Sisyphus 32)"

\section{Philosophical Suicide}

Berthold in his paper wrote, "The philosophies of Soren Kierkegaard and Albert Camus have typically been considered as inverted images of eachother. (138)." It has often been denoted that Albert Camus is an existentialist, to which Camus has totally neglected. Camus further adds that for once and for all he is an absurdist, not even a philosopher but just a novelist. Philosophy of existentialism and absurdism takes its root under similar circumstances. Moreover, they also believe that life is indeed meaningless but there philosophy differ when "...Kierkegaard turns to faith in God as a path of redemption from meaninglessness while Camus rejects faith as a form of intellectual suicide and cowardice. This is no doubt a significant difference (Berthold 138)".

According to Camus, one does not have to put their belief in an exterior entity to go through life. Moreover, if they will do and put their belief on an exterior entity, they won't be able to live their life the way they want because rather than finding the answers and building their own meaning in the meaninglessness, they have already filled up the gaps with putting their belief on God. Camus narrating the remark from the Chestovian philosophy in The Myth of Sisyphus writes, '“The only true solution,' he said, 'is precisely where human judgment sees no solution. Otherwise, what need would we have of God? We turn towards God only to obtain the impossible. As for the possible, men suffice (37)." Camus touch and questions human mind and their condition to bring the meaning out of something, out of love to do something, rather than fear. Camus writes "if in order to elude the anxious question : 'What would life be ?' one must, like the donkey, feed on the roses of illusion, then the absurd mind, rather than resigning itself to falsehood, prefers to adopt fearlessly Kierkegaard's reply : 'despair'. Everything considered, a determined soul will always manage (The Myth of Sisyphus 43)."

In Kierkegaard's existentialism, we come across that all the dots are close and there is not much space where an individual can create but just react in one or the other. Thus, Camus in same sense argues and neglect the concept of existentialism as an act of cowardice. Moreover, Camus goes on to classify it under "Philosophical Suicide" in his work The Myth of Sisyphus (32). Camus dragging his argument from the section of "absurdity and suicide" goes on to neglect the philosophy of existentialism and portrays his idea of absurdism supreme to the other. Camus stands on his statement that the only way to live life is to accept the irrationality of the world, which will later turn out to be meaningful as one goes along. "The very concept of what it means to be a human in this world was revised dramatically and irreversibly to fit the categories of victims, perpetrators, bystanders, and heroes, (mis)shaped by the event and the bureaucratic order that invented and 
implemented the techniques for its enactment (Robinson 3)."

\section{The Absurd Man}

As the title of the book suggest, Sisyphus is the absurd man of Camus's masterpiece and moreover, Camus see no distinction between Sisyphus's punishment and mortal human life, he takes Sisyphus as the prime example to teach us what human life is and what we can make out of it. "They had thought with some reason that there is no more dreadful punishment than futile

and hopeless labour (Camus, The Myth of Sisyphus 107)". Camus believes that each individual goes on to do something similar throughout their life but does that make them an absurd man.

Camus writes "He who, without negating it, does nothing for the eternal. Not that nostalgia is foreign to him. But he prefers his courage and his reasoning. The first teaches him to live without appeal and to get along with what he has; the second informs him of his limits. Assured of his temporally limited freedom, of his revolt devoid of future and of his mortal consciousness, he

lives out his adventure within the span of his lifetime (The Myth of Sisyphus 64)."

According to Camus, the definition of an absurd man is a simple conscious human who knows the difference of everything and takes the side of love, creating his own meaning keeping in mind the circumstances of life. Camus writes in The Myth of Sisyphus "To a conscious man old age and what it portends are not a surprise (71)." Moreover, Camus further adds, "This madman is a great wise man. But men who live on hope do not thrive in this universe where kindness yields to generosity, affection to virile silence, and communion to solitary courage (The Myth of Sisyphus (68).”

Camus while describing Sisyphus writes, "His scorn of the gods, his hatred of death, and his passion for life won him that unspeakable penalty in which the whole being is exerted towards accomplishing nothing (The Myth of Sisyphus 108)." While, we see that Camus has seen little difference between Sisyphus's punishment and human life, what he is pointing out is humans are free to create their own meaning and purpose but they will only be happy when they accept the absurdness, the meaning will only be added when they accept the meaningless. "In Sisyphus we are therefore presented with the absurdity of repetition, and here Camus draws attention to human behaviour in both a narrow and broader sense. More narrowly, he emphasizes the 'mechanical aspects' of human 'gestures', for this 'meaningless pantomime makes silly everything that surrounds them' (Plant 119)." Camus adds how
Sisyphus is accepting the absurdness to change it "That hour like a breathing-space which returns as surely as his suffering, that is the hour of consciousness. At each of those moments when he leaves the heights and gradually sinks towards the lairs of the gods, he is superior to his fate. He is stronger than his rock (The Myth of Sisyphus 109)."

The absurd man of Camus, which he states and want, everyone to follow to live a happy life is accepting every situation and finding meaning in it. As mentioned by Camus that human life is in some way like, Sisyphus's punishment, the single most thing that one can do to kill the punishment is find happiness in it. "I leave Sisyphus at the foot of the mountain! One always finds one's burden again. But Sisyphus. teaches the higher fidelity that negates the gods and raises rocks. He, too, concludes that all is well. This universe henceforth without a master seems to him neither sterile nor futile. Each atom of that stone, each mineral flake of that night-filled mountain, in itself forms a world. The struggle itself towards the heights is enough to fill a man's heart. One must imagine Sisyphus happy (Camus, The Myth of Sisyphus 109)."

\section{Metamorphosis}

David Wyllie in the preface of Metamorphosis writes how this work is an autobiographical piece of writing and we could find ample of reflection from Kafka's life in this story. 'Kafka's popularity is most conspicuous in the appearance of the adjective Kafkaïen (Kafkaesque), which, in addition to its original meaning ('belonging to the Prague author Kafka'), acquired the pejorative connotation of describing an absurd situation in general and became a fashionable term (Bogaerts 71)." Max Brod, Kafka's biographer has often written about the curious thought that Kafka had about the world and most of them, laid in nihilistic perception. When Max Brod, asked, "if there is hope", Kafka replied "plenty of hope, for god, only not for us." It is often been stated that to study, the works of Kafka, one should examine, Kafka's, belief and his ideas which had a major impression in his life. As it has already been mentioned about Kafka and his relation with his father. Kafka has exactly portrayed that image in form of Gregor in Metamorphosis. The masterpiece of the $20^{\text {th }}$ century, absurdist world Metamorphosis, written by Franz Kafka is so beautifully collected in different ways, that the beauty create a prolific mysterious effect and with too many interpretation of the same world. The book is an answer and an enigma at the same time. (Kafka, 9-14)

\section{Metamorphosed}

Kafka's Metamorphosis opens up with one of the best opening line in literature. "One morning, when Gregor Samsa woke from troubled dreams, he found himself 
transformed in his bed into a horrible vermin (15)." We get couple of questions from this few lines, that how is it possible and how it happened? However, as it often goes with Kafka, his stories often move around with a feeling of alienation and meaninglessness and this in other words is termed as a world of "Kafkaesque". In this world, things happen for reason unknown and it depends more upon the reader on how they want to consume it. Moreover, the subtle use of Magical Realism is also been seen in this work.

As the story progress, we come to know about Gregor's profession, he is a travelling salesman and he hates his job. $\mathrm{He}$ is only doing it because of the need of his family and because his family is depended on him. "If I didn't have my parents to think about I'd have given my notice a long ago, I'd have gone up to the boss and told him just what I think, tell him everything I would, let him know just what I feel (17)."

The labyrinth that Kafka builds around readers is that of expectations, moreover a reaction of the metamorphosed body of Gregor but for Gregor there are far more important things to achieve like catching his train and appearing to the office. Kafka specifically highlight how Gregor has never taken a single leave in fifteen years and his job is lot more important than the reaction of his metamorphosed body. Moreover, we also see a part where corporate life is been dictated, a sleep of even half hour is been portrayed as a luxury.

With time, we see that his family start reacting because it was weird that Gregor was home and not at work and it came as a surprise for them. Moreover, even the headclerk came into check on Gregor and start reacting on laziness but soon enough, Gregor opens the door and reveals him. The head-clerk cries "Monster". The family is in shock and furthermore, as Gregor steps out, his father badly beat him that lead to severe bleeding and pushes Gregor back in his room and closes the door behind him to shut Gregor inside (Kafka 15-40).

\section{Living as a vermin}

Kafka has divided Metamorphosis in three sections, which he has not named but could be counted as Starting, middle and the end. The middle is when Gregor has accepted his new life and has started living with it. While, on the first few days when he was hungry, he was not able to find goodness in the food that was served to him and thus, his sister has to change his meal to "...Half-rotten vegetables, bones from the evening meal, covered in white sauce that had gone hard, a few raisins and almonds, some cheese that Gregor has declared inedible two days before, a dry roll and some bred spread with butter and salt (Kafka 47)."
The Change in the behaviour of the family members is been clearly portrayed by Kafka, with Gregor's father and mother not really accepting the creature as his own son. Gregor's sister is the only one who is coming to the rescue to save him, serve him food and occasionally clean his room but whenever she use to come to his room, Gregor use to lay down under the couch, so that he doesn't come in the site of his sister (Kafka 47-50).

Even while living his life as a vermin, Gregor's concern was family's prospect and finances. Alone in his room, Gregor started experimenting on how the life as a vermin goes and moreover, started climbing the ceiling of his room and use to spent his time sitting on a chair which was next to the window giving the view of a hospital (Kafka 50-55).

Greta, Gregor's sister was the first one to notice of Gregor's changing behaviour. "... traces of the adhesive from his feet as he crawled about... (Kafka 59)." Thus, due to this Greta suggested that how about they take away all the furniture from his room but his mother rightly stated “... won't it seem like we're showing that we've given up all hope of improvement and we're abandoning him to cope for himself? (Kafka 60)." Here, in the story with his mother's reaction we see that she mentions hope for improvement, while Kafka spends no time in correcting or even elucidating on what they are particularly hoping for. Another major point is, if the mother and even father is hoping to change something, have Gregor and Greta accepted the new life that Gregor is living? While all these questions are needful, the answers are not served by Kafka. (Kafka 55-63).

With time, Greta's idea of removing the furniture was accepted to give Gregor more space to live in and thus, one after the other all the things that were dear to Gregor was taken away and shifted to another place. Kafka has taken things from his life and portrayed in the story. His father's anger, sister's love, and his mother's commitment to his son. When the father came home one day, while they were switching the things from Gregor's house back out. He found that his wife has fainted and when he asked, Greta. She replied, "Gregor got out." However, the father got so angry at the simplest thing that he severely beat Gregor and it was Greta who came between the beating to stop his father and spare the life of Gregor (Kafka 63-70).

The second section is more like a See-saw, Gregor trying to accept the new life that he is been served with and their family not accepting it and moreover, at times helping Gregor but the emotions that they are portrayingoutside Gregor's room is killing Gregor inside. The simplest things are taken heavily and above all his father's anger is 
the fundamental emotion somewhere portrayed in all its glory.

\section{A bad close to a good life}

"No-one dared to remove the apple lodged in Gregor's flesh, so it remained there as a visible reminder of his injury. ... Because of his injuries, Gregor had lost much of his mobility - probably permanently (Kafka 71)." From the beginning of section three itself, we smell that the close is near, Gregor is been badly injured and even his movement is taken away. Moreover, Kafka even mentions, "Crawling over the ceiling was out of question (71)". Everything that was close to him was taken away, his crawling to the ceiling or the furniture that kept him accompanied, giving him a feel that he was at home. The family even started battling with the thoughts of Gregor; his father would not remove his uniform even when he was home. His mother was eating less than usual and his sister started working to pay for his own finances. The suffering the Gregor brought home was seen. Moreover, even Greta stopped going into Gregor's room, which became tidy now. "Smears of dirt were left on the walls, here and there were little balls of dust and filth (Kafka 77)".

The family got so tired with Gregor that they even stopped feeding him, "“'I'd like to eat something" said Gregor anxiously, "but not anything like they're eating. They do feed themselves. And here I am, dying!"'. The last pint of hope that Gregor was carrying with him in the tough times was his sister who eventually gave up on him. "“Father, Mother," said his sister, hitting the table with her hand as introduction "we can't carry on like this. Maybe you can't see it, but I can. I don't want to call this monster my brother, all I can say is: we have to try and get rid of it (Kafka 88)."”,

As often, it happens in the works of Kafka that the characters are not given many choices and the ways to behave to get out of the situation are very less because the plots are been seized in such a way. In Metamorphosis while the family is tired and especially Gregor, his father mention, "If he could just understand us (Kafka 89)." Insight inside Gregor's mind is not given but if we look the life from the side of Gregor neither does Gregor has any choice left. Moreover, the house to which he served for atleast fifteen years, are letting go of him because of a small instance. Human Emotions are conveyed by Kafka that without the use and importance of an individual how he is neglected and considered unimportant.

With time, even Kafka understood what the family had been suffering because of him and thus, he stopped eating when the food was at times served to him. "Just look how thin he was. He did not eat anything for so long. The food came out again just the same as when it went in (Kafka
94). With a small incident again, when Gregor came out of his room and his father has to take his beating ahead, we see that it was the last straw of pain for Gregor and the next day, the cleaning lady found him dead, not eating.

The climax is quite intrigued because the family took a sign of relief and felt like a family after Kafka's death. One question we have to pressurized ourselves and ask is, what is the pressure the family put on Gregor that he stopped eating and choose death or did he choose death because of his own helplessnessor was he thrown off the bridge of patience. The answer are interpretations because the story is a maze.

\section{Acceptance as a revolt to life.}

In the author's introduction Albert Camus mentions "To say that life is absurd, one must be alive (The rebel $\mathrm{X}$ )." The idea of absurdism that Camus provides is been prolifically seen in the Kafka's novella, Metamorphosis. Using Camus's critical essays, as the base we see the philosophy of absurdism and it comes alive when put in context with Metamorphosis.

"The critics' opinions vary along with their understanding of Camus' philosophical position. ...

Although some of these same astute critics have pointed to the derivative Kafkaesque qualities of Camus' writings, no one of them has done an extended comparative treatment of the two authors

(Rhein 3)."Absurdness or Meaninglessness can be seen from the starting of the book but Gregor, the protagonist of Metamorphosis live through it. Gregor accepts the new life that it given to him in form of a little-vermin and even while he is not able to do most of the task, like turning around or laying on its back which came to him easily when he was human was a difficult task now, but rather than denying it as absurd Gregor has started finding meaning in it.

"Camus finds it extremely difficult to speak of symbols in writings such as Kafka's, which are predominantly "natural in quality." The particular quality of naturalness employed by Kafka is not easily understood. According to Camus, there are writings in which the events appear natural to the reader; and less frequently, there are writings in which the characters find everything that happens to them to be natural. Through a singular but evident paradox, the more extra- ordinary the adventures of a character are, the more perceptible the natural qualities of the work will be (Rhein 4)." Camus wrote that the acceptance of the absurdness would be a revolt to life. Gregor can be seen performing this task, so is Sisyphus, while the different is lengths apart because Sisyphus reached to the punishment because of his deed and Kafka has not mentioned anything about how 
Gregor changed as a little vermin or what was the reason, it was open to interpret for every reader for themselves. Acceptance of Gregor comes easy because of the backstory of his life as a travelling salesman which he hated to start with and was only doing it for his family but Kafka has not mentioned into detail the reason why he was holding back on his job but we could find that even while being wrapped with responsibility, underneath was love, which was the reason. The meaning that Gregor derived with his futile repetition.

Another reason is the Head-clerk coming to the house, we can assume that Gregor was one of their greatest assets or why would the clerk come to the house to check upon a fellow salesman. Battling with the irrational, Gregor is been seen to do something new every day. At times either it be to eat different food or it be exploring how the body of the little vermin works, like crawling on the ceiling or squishing behind places to know more about it. Devour of faith and love can be seen in this work, while Gregor mentioned the love for his room and aroma with settlement. Greta and her mother thought to take away the furniture and everything away. Even when that, happened Gregor had hold on to the irrationality of life to turn into something better. Gregor's mother has been seen mentioning about the "change", hoping for change and the change while not been mentioned binds in the favour of Gregor's mentality to acceptance.

Throughout whole of Kafka's Metamorphosis, there is no mention of an external entity or what the Greeks call "Deus ex machina". Though, we see the subtle use of magical realism throughout the story, there is no trust or hope or even thought that is been approved that states anything unusual or a help that is going to come in life of Gregor which take away the concept of "Philosophical Suicide" away from Metamorphosis and make it more focused on Gregor Samsa as an absurd man.

\section{CONCLUSION}

Can one Imagine Gregor Samsa happy?

"Most critics have defined Kafka's works as a cry of desperation (Rhein 9)." Kafka's life cannot be taken away from his stories in some ways because it is so interwined and his life been full of struggle, his works are considered to have a pessimistic touch. "Camus recognizes that Kafka's heroes know in advance that they will gain nothing from their quests and that they allow themselves the torturing luxury of pursuing their goal until death (Rhein 7)." This perception that Camus writes on Kafka's work opens new interpretation for fellow readers like us. While knowing the end, we have couple of routes and one being accepting the fate and creating our own meaning and purpose, which is basically the idea of absurdism by Camus, in some ways we see that Kafka's characters lay in between both of them. "The word hope as applied to Kafka is not ridiculous, for the more tragic the condition reported by Kafka becomes, the more rigid and super rational the hope must be (Rhein 8)." The need of hope is only possible because there is constant struggle that one goes around within Kafka's stories.

"While the estrangement of Kafka's heroes is expressed by a discrepancy between the action and the spoken word, their gestures and attitudes often bear the promise of reconciliation. ... In addition to illuminating the predicament of Kafka's characters, the failure of the spoken word sheds light on the limitations of language itself (Darzins 119)." Moreover, then the language, as the story moves, the need of language becomes an action in itself and taking that away is thrashing the protagonist in the dark side.

The major contradiction that lies between Sisyphus and Gregor is that of their end. While, we know that Sisyphus being immortal is punished to roll the boulder for eternity. Gregor Samsa on the other end, accepts the end, stops eating his food and in some way, we can interpret denies the irrationality and accepts death. Thus, if we interpret Samsa in that manner, he is not the absurd man but in the same case, we cannot deny that Gregor was a mortal being suffering from pain.

If we are still asked, if one can Imagine Gregor Samsa happy? The answer would be "NO". One cannot in some circumstances do that but Kafka's portrayal of Samsa was the need of the hour. Kafka describes his world in a brutal way because indeed, it is and one must, Like Gregor Samsa learn to accept it. There is struggle, feeling of estrangement, alienation and lot more, but like Sisyphus, one must keep going back to the boulder and create their ownmeaning and purpose to be happy.

\section{REFERENCES}

[1] Berthold, Daniel. "Kierkegaard and Camus: either/or?". International Journal for Philosophy of Religion, April 2013, Vol. 73, No. 2 (April 2013), pp. 137-150. https://www.jstor.org/stable/24709214.

[2] Camus, Albert. The Myth of Sisyphus. Penguin Modern Classic. 1979.

[3] ---. The Rebel. Penguin Classics. 1953

[4] Darzins, John. "Transparence in Camus and Kafka." Yale French Studies, 1960, No. 25, pp. 98-103, https://www.jstor.org/stable/2928909.

[5] Kafka, Franz. Metamorphosis. Fingerprint Classics. 2018.

[6] Mikics, David and Robert Zaretsky. "From Solitude to Solidarity: How Camus Left Nihilism Behind". The 
Virginia Quarterly Review, SPRING 2013, Vol. 89, No. 2, pp. 201-204. https://www.jstor.org/stable/26446761.

[7] Nietzsche, Friedrich. The Gay Science. Vintage books. 1974.

[8] Pritchard, Duncan. "Absurdity, angst, and the meaning of life." The monist, January, 2010, Vol. 93, No. 1, pp. 3-16, https://www.jstor.org/stable/41419194.

[9] Rhein, H. Phillips . "Kafka and Camus." University of North Carolina press, 1964.

[10] Robinson, E, James. "SISYPHUS HAPPY: Beckett beyond the Absurd". Aujourd'hui, 1997, Vol. 6. pp. 343-352. https://www.jstor.org/stable/25781232.

[11] Zaretsky, Robert. The Tragic Nostalgia of Albert Camus. Historical Reflections, WINTER 2013, Vol. 39, No. 3, pp. 55-69. https://www.jstor.org/stable/42703771. 